\title{
Modelling greenhouse gas emissions of cacao production in the Republic of Côte d'Ivoire
}

\author{
W. Vervuurt $\mathbb{D} \cdot$ M. A. Slingerland $\mathbb{D} \cdot$ A. A. Pronk $(\mathbb{D} \cdot$ L. G. J. Van Bussel $\mathbb{1}$
}

Received: 20 July 2021 / Accepted: 30 December 2021 / Published online: 29 January 2022

(C) The Author(s) 2022

\begin{abstract}
The current expansion of cacao cultivation in the Republic of Côte d'Ivoire is associated with deforestation, forest degradation, biodiversity loss and high greenhouse gas (GHG) emissions. Global concerns about emissions that are associated with tropical commodity production are increasing. Consequently, there is a need to change the present cacao-growing practice into a more climate-friendly cultivation system. A more climate-friendly system causes lower GHG emissions, stores a high amount of carbon in its standing biomass and produces high cacao yields. GHG emissions and carbon stocks associated with the present cacao production, as assessed in 509 farmers'
\end{abstract}

W. Vervuurt $(\bowtie)$

Wageningen Plant Research, Wageningen University and Research, Edelhertweg 1, 8219PH Lelystad, The

Netherlands

e-mail: wieke.vervuurt@wur.nl

W. Vervuurt · M. A. Slingerland

Plant Production Systems Group, Wageningen University and Research, P.O. Box 430, 6700AK Wageningen, The

Netherlands

W. Vervuurt · L. G. J. Van Bussel

Environmental Systems Analysis Group, Wageningen

University and Research, P.O. Box 47,

6700AA Wageningen, The Netherlands

\section{A. A. Pronk}

Wageningen Plant Research, Wageningen University and Research, Droevendaalsesteeg 1, 6708PB Wageningen,

The Netherlands fields, were estimated by using the Perennial GHG model and the Cool Farm Tool. On average, the production of $1 \mathrm{~kg}$ cacao beans is associated with an emission of $1.47 \mathrm{~kg} \mathrm{CO}_{2} \mathrm{e}$. Deforestation contributed largely to GHG emissions, while tree biomass and residue management contributed mainly to carbon storage. The collected data combined with the model simulations revealed that it is feasible to produce relatively high yields while at the same time storing a high amount of carbon in the standing biomass and causing low GHG emissions. The climate-friendliness of cacao production is strongly related to farm management, especially the number of shade trees and management of residues. Calculated emissions related to good agricultural practices were $2.29 \mathrm{~kg}$ $\mathrm{CO}_{2} \mathrm{e}$ per $\mathrm{kg}$ cacao beans. The higher emissions due to the use of more agro-inputs and other residue management practices such as recommended burning of residues for sanitary reasons were not compensated for by higher yields. This indicates a need to revisit recommended practices with respect to climate change mitigation objectives.

Keywords Cacao cultivation - Climate-friendly . GHG emissions · Agricultural intensification 


\section{Introduction}

Sales of cacao provide income for millions of smallholders in Côte d'Ivoire and Ghana. These smallholders are responsible for about $70 \%$ of all cacao produced globally (Wessel and Quist-Wessel 2015). Cacao plantations can be managed in very different manners, ranging from traditional low input agroforestry systems to intensive monocultures (Recanati et al. 2018). In Côte d'Ivoire, cacao trees are traditionally planted under a thin forest shade, using the forest soil fertility (Wessel and Quist-Wessel 2015). However, the shift towards monocultures (fullsun) has recently increased (Wessel and Quist-Wessel 2015; Schroth et al. 2016).

Management practices (MPs) in cacao plantations include the use of fertiliser, shade management, pruning and waste management. A number of organic and inorganic fertilisers are used in cacao, including urea, manure, organic residues and chemical fertilisers. These can be applied in the planting hole, in a circle around the stem or by foliar application and differ in dosages (Recanati et al. 2018). The effect of applying fertilisers on biomass growth is mediated by the shading intensity (no, medium, or heavy), depending on pruning practices and shade trees (van Vliet and Giller 2017). Shade trees commonly include timber trees such as $C$. alliodora, leguminous trees such as $E$. poeppigiana and fruit trees such as orange, avocado and mango. Overall, shade trees account for a large part of the total aboveground biomass of the plantation (Beer et al. 1990; Dawoe et al. 2016). Pruning waste, as well as pod husks and other residues in the fields are commonly burnt or composted (van Vliet and Giller 2017). With all these different management options, the impact on the environment varies across plantations depending on the cultivation type (Recanati et al. 2018).

In many tropical countries, there is a need for intensification of agriculture to increase yields and incomes which tend to cause an increase of greenhouse gas (GHG) emissions per ha (Schroth et al. 2016). At the same time, global concerns about anthropogenic GHG emissions and concerns about environmental issues associated with tropical commodity production are rising (Neslon and Phillips 2018). Consequently, there is an urgent need to change the present cacao production into a more sustainable cultivation system with lower GHG emissions per unit of product with similar or even higher yields (Schroth et al. 2014).

Although the carbon stock in cacao plantations is extensively researched, little is known about the GHG emissions associated with current cacao production (e.g. Gama-Rodrigues et al. 2011; van Rikxoort et al. 2014). It is highly debated whether the production of cacao is associated with net GHG emissions or net storage of carbon (Ortiz-Rodriguez et al. 2016; Defra 2009; Schroth et al. 2016; Montagnini and Nair 2004). On the one hand, forest conversion to cacao land, burning organic material, a common practice in current cacao production systems, and applying fertiliser is associated with GHG emissions (Ledo et al. 2018). While on the other hand, perennials, such as cacao, also have the potential to store carbon in their standing biomass (Dawoe et al. 2016; Schroth et al. 2014) and to add soil carbon through litter and plant roots, which decompose and form soil organic carbon (Ledo et al. 2018).

As farm management is a potential tool for GHG emission mitigation, understanding the relations between MPs and the associated GHG emissions is a prerequisite for developing actions related to the reduction of GHG emissions. To enable management to be recommended, sources of GHG emissions first need to be identified and quantified (Ledo et al. 2018).

Agricultural intensification is seen as a solution to improve yields and income, but might have an adverse effect on the environment. However, increased yields may compensate for the increase in GHG emissions, resulting in similar GHG emissions per kilogram of product. The question arises to what extent intensification of the cacao production can be considered climate friendly.

As acknowledged by Recanati et al. (2018) and Silatsa et al. (2017), deeper research is needed on the environmental impact of various cacao cultivation systems, including the emission of GHGs of these systems.

Therefore we aim to: (1) quantify the GHG emissions resulting from various farm level activities in cacao plantations in Côte d'Ivoire, (2) investigate to what extent large carbon stocks and low GHG emissions are compatible with high cacao yields, and (3) quantify the GHG emissions and carbon stock associated with agricultural intensification.

In order to calculate the GHG emissions associated with cacao production, farm level data from an 
extensive survey and field data on cacao biomass were used as input for two existing assessment tools, which were improved as part of our study.

\section{Methodology}

System boundaries

To classify the climate impact of agricultural commodities, Van Rikxoort et al. (2014) propose to consider standing carbon stocks and the production related GHG emissions as two dimensions of climatefriendliness. Schroth et al. (2016) apply this concept to assess cacao production systems in Brazil. In our study, yields per hectare are added as a third dimension to include also a socio-economic sustainability factor.

We define climate-friendly cacao as cacao produced in systems with above median carbon stocks, above median yields and below median GHG emissions. Medians are calculated on the basis of all plots in the study area. Carbon stocks are expressed in tonnes of $\mathrm{C} \mathrm{ha}^{-1}$, yields are expressed in $\mathrm{kg}$ semi-dry cacao beans ha ${ }^{-1}$ and GHGs are expressed in $\mathrm{kg} \mathrm{CO}_{2} \mathrm{e}$ $\mathrm{ha}^{-1}$. The evaluation of the GHG emissions of cacao production in our study is based on the methodology developed by Ledo et al. (2018). The farm boundary approach is used, assessing the annual GHG stored and emitted at the farm in Côte d'Ivoire. A schematic overview of the sources and sinks of the GHG emissions and carbon stocks taken into account are presented in Fig. 1. The sink is carbon $(\mathrm{C})$ and sources of GHG include carbon dioxide $\left(\mathrm{CO}_{2}\right)$, nitrous oxide $\left(\mathrm{N}_{2} \mathrm{O}\right)$ and methane $\left(\mathrm{CH}_{4}\right)$. The net (positive or negative) emission is expressed as $\mathrm{CO}_{2} \mathrm{e}$, using global warming potentials of 298, 34 and 6.7, respectively, for $\mathrm{N}_{2} \mathrm{O}, \mathrm{CH}_{4}$ and $\mathrm{C}$ (Myhre et al. 2013). A positive emission indicates that the sources are larger than the sinks, and a negative emission indicate that the sinks are larger than the sources.

\section{Emissions resulting from farm level management}

Farm management affects GHG emissions in various ways (Recanati et al. 2018; Ledo et al. 2018; Schneidewind et al. 2018). The farm level activities of 372 individual farmers were sourced from a survey conducted by Ingram et al. (2013), referred to as the

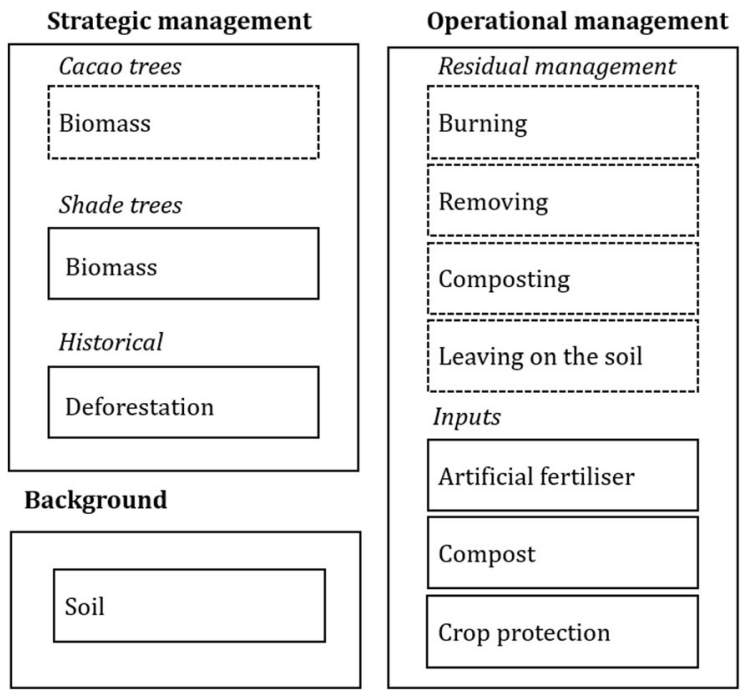

Fig. 1 Schematic overview of sources and sinks of GHG emissions considered in our study. Dotted lines indicate that GHGs and carbon stocks are modelled by using the perennial GHG model and solid lines indicate GHGs and carbon stocks modelled by using the CFT

UTZ survey. The GHGs resulting from the following farm management activities are assessed.

Cacao trees It is generally accepted that cacao tree standing biomass functions as a carbon sink (see e.g. Mohammed et al. 2016; Schneidewind et al. 2018; Somarriba et al. 2013). Our study estimates the carbon storage per hectare and the annual carbon accumulation on the basis of the number of cacao trees per hectare, plantation age, carbon content of the cacao tree organs and pruning regime. The number of cacao trees per hectare is a substantial determining factor for the carbon stored in standing biomass. Unfortunately, the number of cacao trees per hectare was not well recorded during the UTZ survey. Therefore, the number of cacao trees per hectare is assumed to be 1111 trees per hectare for each plot, irrespective of the presence of shade trees. This assumption was made on the basis of the findings of Ngala (2015), who reported that the cacao tree density did not differ significantly between full sun and agroforestry systems, implying that replacement of cacao trees by shade trees does not occur.

Residues Many residues are produced in cacao plantations. These residues can be managed in various manners. In our study, the GHGs resulting 
from leaving these residues on the soil, exporting these residues from the farm and burning or composting these residues are taken into account. The cacao residues assessed in our study include leaf litter, cacao husks, infected fruits and pruning residues.

Inputs The inputs considered include mineral and organic fertiliser and pesticides (Schroth et al. 2016). The GHG emissions per unit of fertiliser and pesticide are presented by Hillier et al. (2011) and include emissions resulting from the production and distribution of fertilisers and pesticides. Because of data availability, our study only assessed GHG emissions from using pesticides, compost and compound NPK (15:15:15).

Shade trees Cacao fields are generally established by slash and burn practices (Gockowski and Sonwa 2011). Therefore, it is assumed that cacao and shade trees are planted simultaneously by the farmers. As a consequence, shade trees are classified as farm management. Shade trees can store significant amounts of C (Somarriba et al. 2013). Although many different tree species can be found in cacao plantations in Côte d'Ivoire (Henry et al. 2011), our study does not differentiate between the various characteristics of these species, because of data availability. In our study, the carbon storage per hectare and annual accumulation is calculated in the Cool Farm Tool (CFT), on the basis of stem diameter. As the latter is not obtained for each respondent, the diameter is estimated on the basis of tree age (x) by using a function obtained from Onyekwelu (2007):

Diameter of shade tree biomass $(\mathrm{cm})$

$$
=21.648 \times \ln (x)-18.705
$$

where $x$ is tree age in years. According to Ingram et al. (2017), farmers were not able to indicate the shade tree spacing correctly, generally overestimating the number of shade trees per hectare. The maximum number of shade trees was therefore restricted to 21 shade trees per hectare, based on the findings of Dumont et al. (2014).

Deforestation The effect of deforestation on the GHG emissions from cacao production is estimated by the CFT, annualising the carbon stock change because of deforestation over the past 20 years (Schroth et al. 2014).

\section{Emissions resulting from soil processes}

Background emissions are unrelated to MPs and are included in our study to assess the relative effect of MPs on the climate-friendliness of cacao production systems. The background emissions considered result from soil processes. Emissions from the soil are determined by the soil texture, soil organic carbon (SOC), $\mathrm{pH}$, drainage and climate and are expressed as yearly $\mathrm{CO}_{2}$ emission resulting from a change in $\mathrm{C}$ stocks (Hillier et al. 2011). Positive emissions indicate a loss of soil carbon, negative emissions indicate a net storage of carbon in the soil. Soil characteristics are retrieved from the ISRIC database (ISRIC 2019) on the basis of GPS-coordinates of the respondents. Since GPS-coordinates were not individually recorded, GPS-coordinates on the basis of the department of the respondents were used.

\section{Modelling}

To calculate the carbon stocks and GHG emissions resulting from cacao production, two independent models were used: the CFT and the perennial GHG model. The CFT was used to estimate the GHGs of the background, shade trees and inputs, and the perennial GHG model was used to estimate carbon storage of the cacao trees and the GHG emissions of the residue management (see Fig. 1). The models do not interact with each other but provide separate outputs that together add up to the total emissions of the cacao fields.

\section{The CFT}

The CFT is an Excel-based tool developed by Hillier et al. (2011), estimating GHG emissions of agricultural production, using empirical equations and the IPCC Tier 1 and 2 approaches. Clavreul et al (2017) performed a sensitivity analysis on the model parameters, using actual parameter ranges found in literature, and conclude that the sensitivity of the model parameters is low, except for GHG emissions from fertiliser production and the $\mathrm{N}_{2} \mathrm{O}$ emissions resulting from the $\mathrm{N}$-input. The nitrogen use on cacao plots (0-250 $\mathrm{kg} \mathrm{N} \mathrm{ha}^{-1}$ ) is lower than the range in nitrogen 
use (66-506 $\mathrm{kg} \mathrm{N} \mathrm{ha}^{-1}$ ) applied by Clavreul et al (2017), and hence, the uncertainties in our study will be lower. Furthermore, Clavreul et al (2017) showed that small farms are characterised by larger variability in GHG emissions per tonne product than larger ones. Since larger farms had a higher yield per hectare, Clavreul et al (2017) propose to weight farm results in terms of GHG emissions by production volume if the objective is to obtain a carbon footprint for the total production in a given region. Plot size was not correlated with yield levels in our data set, but given the variability of small farms we weighted farm results by plot size. To get also insights in the effects of farming practices on GHG emissions regardless of the size of the farms, for example to demonstrate change of farming practices within a region or to know the performance of individual farms (Clavreul et al. 2017), we also calculated non-weighted GHG emissions.

\section{The perennial GHG model}

The perennial GHG model is a generic allometric model to estimate biomass accumulation and GHG emissions from perennial food plants production (Ledo et al. 2018). The model simulates biomass accumulation within the plantation and GHG emissions as an effect of farm level activities. The biomass part of the model was not yet parametrised for cacao, which was done as part of our study. The required data for parameterisation include the biomass quantities, nitrogen, carbon and dry matter content and decomposition rate of the cacao tree organs, and the percentage of infected fruits. Data were obtained from 40 studies, mainly based on destructive sampling and modelling (see Appendix 1). A simple sensitivity analysis was performed on the perennial GHG model to identify which parameters of the model are sensitive, i.e. which parameters have a relatively high impact on the model outcomes. This information was used to decide whether the accuracy of the model could be improved by measurements, instead of data sourced from literature. The results of the sensitivity analysis are presented in Appendix 2. The sensitivity analysis showed that the perennial GHG model was sensitive to variations in cacao yield and the dry matter content. Moreover, data regarding the various parts of the cacao fruit were limited. Therefore, fieldwork was executed to collect data on cacao fruits. Furthermore, several adjustments had to be made to the model to make it suitable for modelling cacao tree biomass. An overview of the adjustments made to the perennial GHG model is shown below.

Total aboveground biomass Originally, the perennial GHG model comprised individual modules for cacao tree organs and a separate module for total aboveground biomass. These modules were conflicting as the tree organs did not add up to the total aboveground biomass. Therefore, the separate module for total aboveground biomass was replaced by a sum of the modules of the tree organs.

Pruning The perennial GHG model is able to work with differentiated pruning strategies over time. The UTZ survey includes data on the pruning interval per plot. However, the amount of biomass pruned was not available. To overcome this data gap, the pruning percentage is based on the maximal natural regrowth of the woody biomass simulated by the perennial GHG model.

Fruits Comprehensive information about the cacao fruits is important to calculate the fruit residues and hence the GHG emissions as a result of their management. Since the perennial GHG model is developed for apples, the perennial GHG model assumes fresh fruit biomass to equal yield. Cacao yield is however only the commercial beans (with $8 \%$ moisture content). Consequently, yield and fruit biomass are not equal. Therefore, the perennial GHG model has been adjusted to estimate the dry cacao fruit biomass by multiplying the bean yield by 0.92 divided by the percentage cacao beans.

\section{Fieldwork}

Fieldwork was conducted during November and December 2018, at the Centre National de Recherche Agricole (CNRA) research station, located near Divo, Côte d'Ivoire (5॰46'21.6 “N 5 $5^{\circ} 13^{\prime} 45.4$ ” W). The fieldwork has been conducted in a former fertiliser experiment site which is currently used for research on pruning. The trees were 10 years old and spaced at 2.5 by $3 \mathrm{~m}$, resulting in 1,333 trees per hectare (Calvo Romero 2018). The field experiment is a monoculture consisting of 4 by 6 subblocks. In each block, $5 \times 6$ cacao trees are planted. All 48 trees in the inner part of 
the fertilised blocks were selected for measurements, to avoid the effect of fertilisation and the boundary effect. All mature fruits from one harvest during the yield peak in November have been collected, marked and counted, following the methodology described by Saj et al. (2017). All samples were classified by fresh weight in the following categories: $<300,300-500$ and $>500 \mathrm{~g}$, based on the weight distribution described by Abenyega and Gockowski (2003), Vriesmann et al. (2011) and Apshara (2017). Two fruits per fresh weight category per subplot were selected, adding up to 48 fruits per weight category. The husk, pulp and beans were separated and their fresh weights noted (following Fassbender et al. 1988; Daymond and Hadley 2008). The ratio between the beans (including the shells) and the husk and pulp was calculated. Subsamples of the components were taken, weighed and dried in a dry oven for $96 \mathrm{~h}$ at a temperature of $70{ }^{\circ} \mathrm{C}$ (Calvo Romero 2018; Daymond and Hadley 2008). These subsamples were weighted again, to calculate the wet to dry weight conversion ratio (Lockwood and Pang Thau Yin 1996).

Farm level data

Both the perennial GHG model and the CFT require data as input regarding farm characteristics and management (see Appendix 1 for an overview of required data). A dataset collected by Ingram et al. (2017) meets the required input for the perennial GHG model and the CFT. This dataset covers 730 farmers, situated across three main agro-ecological zones across the Republic of Côte d'Ivoire. According to Ingram et al. (2017), the farmers participating in the survey are representative for the average farmer in the Ivorian cacao sector in terms of farm age and size. The study was conducted on behalf of UTZ: half of the respondents are UTZ certified and the other half served as a control group. Since data regarding the plantation age, area or yield were missing for 357 farmers, only 373 farmers have been included in the analysis. To explore potential effects of intensification, the carbon stocks and GHG emissions associated with cacao produced following 'good agricultural practices' (GAP) was modelled based on the practices recommended by Ahoutou et al. (2015).

\section{Results}

Cacao fruits

The fresh weight of the fruits varied between 100 and $1,170 \mathrm{~g}$, with a mean weight of $429 \mathrm{~g}$. The fresh weight of the husk varies between 177 and $756 \mathrm{~g}$. The dry matter (DM) percentage of the husk varies between 7 and $23 \%$, with a mean value of $15 \%$. The fresh weight of the pulp and beans varies between 32 and $191 \mathrm{~g}$. The sample contained four bad fruits (either infected or harvested while immature). Neglecting these four samples resulted in a range of the fresh weight of the pulp and beans from 45 to $191 \mathrm{~g}$, with a mean weight of $101 \mathrm{~g}$. The DM percentage of the pulp and beans is on average $33 \%$. All in all, these data result in $61 \%$ husk and 39\% pulp and beans on the basis of dry weight (see Appendix 1). The weighted DM percentage for the fruit on the basis of the husk, pulp and beans is $20 \%$.

\section{Carbon stocks}

The 373 farms cultivated 509 cacao plots. In 335 of the these plots shade trees were recorded. The results of the perennial GHG model showed that carbon stocks per hectare are very diverse. Figure 2 shows that the amount of carbon stored in cacao and shade trees increases with plot age. The proportion of carbon stored in shade trees also increases with plot age because older plots tend to have a higher number of shade trees (data not shown). Furthermore, cacao trees are usually pruned, and therefore the amount of $\mathrm{C}$ stored levels off when plot age increases. Farmers might pay less attention to pruning shade trees, and hence, the amount of $\mathrm{C}$ stored in shade tree biomass increases with plot age. Consequently, the proportion of $\mathrm{C}$ stored in shade tree biomass increases over time. Whether the amount of $\mathrm{C}$ stored in cacao trees is dependent on the number of shade trees cannot be deducted from Fig. 2, as the number of plots with 5-15 shade trees per hectare is limited. The average $\mathrm{C}$ stock in cacao trees was 19 tonnes of $\mathrm{C}$ per hectare, plus 4 tonnes of $\mathrm{C}$ per ha in shade trees. Data regarding the cacao tree biomass are presented in Appendix 3. 

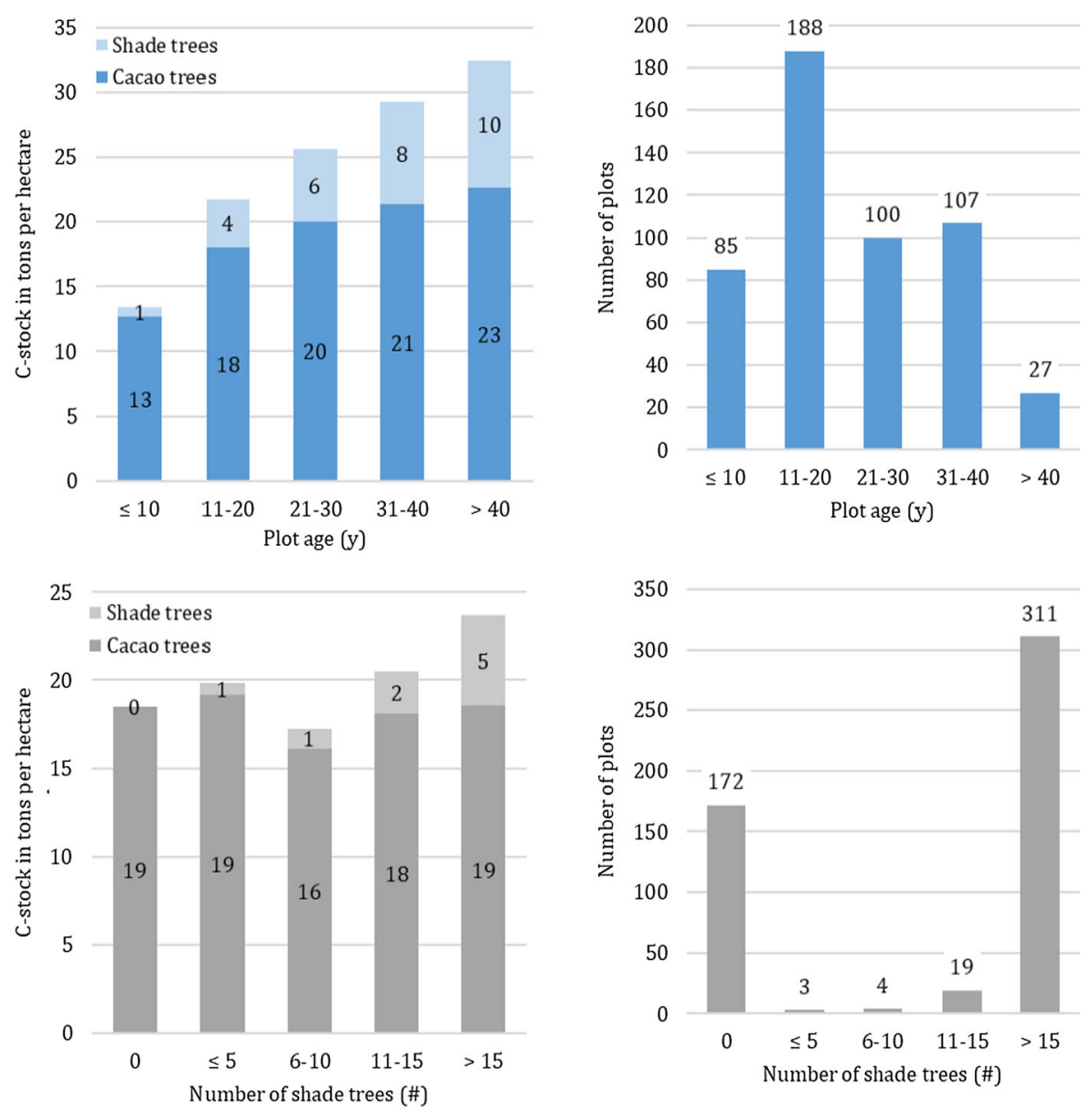

Fig. 2 On the left the number op plots per age class (top) and per category number of shade trees per hectare are presented (bottom), on the right the simulated carbon stocks are presented per age class (top) and per category shade trees per hectare (bottom)

GHG emissions related to farm characteristics and management

Among the different sources of GHG emissions, deforestation contributed the most to positive emissions (see Table 1 and Fig. 3). These emissions even outweigh the negative emissions of cacao- and shade tree biomass. The emissions associated with inputs can be considered low as inputs were rarely used or only in small amounts. Background emissions resulting from soil processes are relatively high when compared to the emissions associated with operational management.
Climate-friendly cacao

High yields, negative emissions and high carbon stocks are compatible, which can be seen in Fig. 4 (the blue triangles in quadrant $\mathrm{A}$ ). The results also show that higher yield levels are not necessarily associated with higher GHG emissions per hectare or a lower carbon stock (data not shown). These results imply potential for sustainable intensification. Of the 509 plots, 232 are associated with negative emissions, 277 are associated with a positive emission and only 66 plots classify as climate-friendly. Plots which are classified as climate-friendly are older and larger and have a higher number of shade trees than plots which are not classified as climate-friendly. Although shade trees contribute largely to negative emissions, a few fields classified as climate-friendly do not have any 
Table 1 The farm characteristics in terms of age, inputs and yield for 509 plots in Côte d'Ivoire, and its modelled weighted and nonweighted carbon stocks and GHG emissions associated with the production of cacao

\begin{tabular}{|c|c|c|c|c|c|}
\hline \multirow[t]{2}{*}{ Expressed in } & & \multirow{2}{*}{$\begin{array}{l}\text { Weighted }^{\mathrm{a}} \\
\text { Mean }\end{array}$} & \multicolumn{3}{|c|}{ Non-weighted ${ }^{b}$} \\
\hline & & & Mean & Median & SD \\
\hline \multicolumn{6}{|l|}{ Farm characteristics } \\
\hline Plot area & In hectares & 3 & 3 & 3 & 2 \\
\hline Pot age & In years & 22 & 22 & 20 & 11 \\
\hline Yield & In $\mathrm{kg}$ per hectare & 443 & 434 & 432 & 318 \\
\hline Shade trees & Number per hectare & 13 & 13 & 21 & 10 \\
\hline \multicolumn{6}{|l|}{ Inputs } \\
\hline Chemical fertiliser & $\mathrm{Kg}$ nitrogen per hectare & 15 & 13 & 0 & 26 \\
\hline Organic fertiliser & $\mathrm{Kg}$ nitrogen per hectare & 45 & 44 & 0 & 78 \\
\hline \multicolumn{6}{|l|}{ Carbon stock } \\
\hline Cacao trees & Tonne $\mathrm{C}$ stored in above- and belowground biomass per hectare & 19 & 19 & 19 & 3 \\
\hline Shade trees & Tonne $\mathrm{C}$ stored in above- and belowground biomass per hectare & 4 & 5 & 5 & 3 \\
\hline \multicolumn{6}{|l|}{ GHG emissions } \\
\hline Cacao biomass & $\mathrm{Kg} \mathrm{CO}_{2} \mathrm{e}$ accumulated yearly per $\mathrm{kg}$ yield & -1 & -2 & 0 & 14 \\
\hline Shade tree biomass & $\mathrm{Kg} \mathrm{CO}_{2} \mathrm{e}$ accumulated yearly per $\mathrm{kg}$ yield & -1 & -2 & -1 & 2 \\
\hline Residue management & $\mathrm{Kg} \mathrm{CO}_{2} \mathrm{e}$ per $\mathrm{kg}$ yield & -1 & -1 & -1 & 4 \\
\hline Deforestation & $\mathrm{Kg} \mathrm{CO}_{2} \mathrm{e}$ per kg yield & 3 & 5 & 0 & 15 \\
\hline Inputs & $\mathrm{Kg} \mathrm{CO}_{2} \mathrm{e}$ per $\mathrm{kg}$ yield & 0 & 0 & 0 & 1 \\
\hline Background & $\mathrm{Kg} \mathrm{CO}_{2} \mathrm{e}$ per $\mathrm{kg}$ yield & 2 & 2 & 1 & 3 \\
\hline Total GHG emissions & $\mathrm{Kg} \mathrm{CO}_{2} \mathrm{e}$ per $\mathrm{kg}$ yield & 1.47 & 2.29 & - & - \\
\hline
\end{tabular}

${ }^{\text {a }}$ Taken into account the plot size

${ }^{\mathrm{b}}$ On the basis of the number of plots, plot size is not taken into account

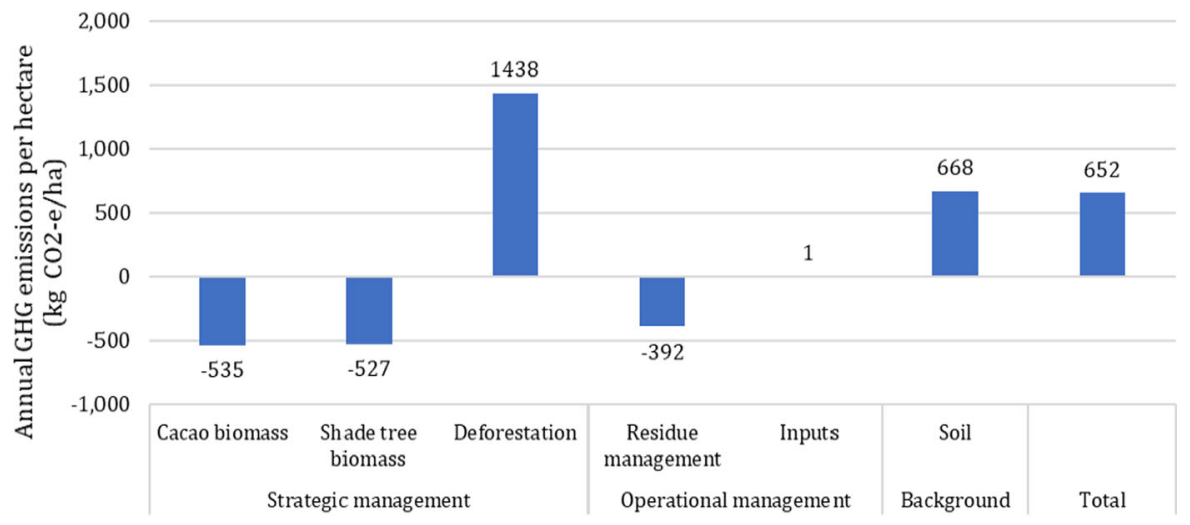

Fig. 3 Annual emission of GHG (expressed as $\mathrm{CO}_{2} \mathrm{e}$ ) on farm per hectare, based on the 509 assessed plots (1722 ha). Positive values mean emissions while negative values mean storage

shade trees. No significant differences in operational management were observed between climate-friendly and the other plots (data not shown).

\section{Good agricultural practices}

GAP (as described by Ahoutou et al. 2015) are associated with a higher use of inputs (fertiliser and 
O Below median yield $\Delta$ Above median yield

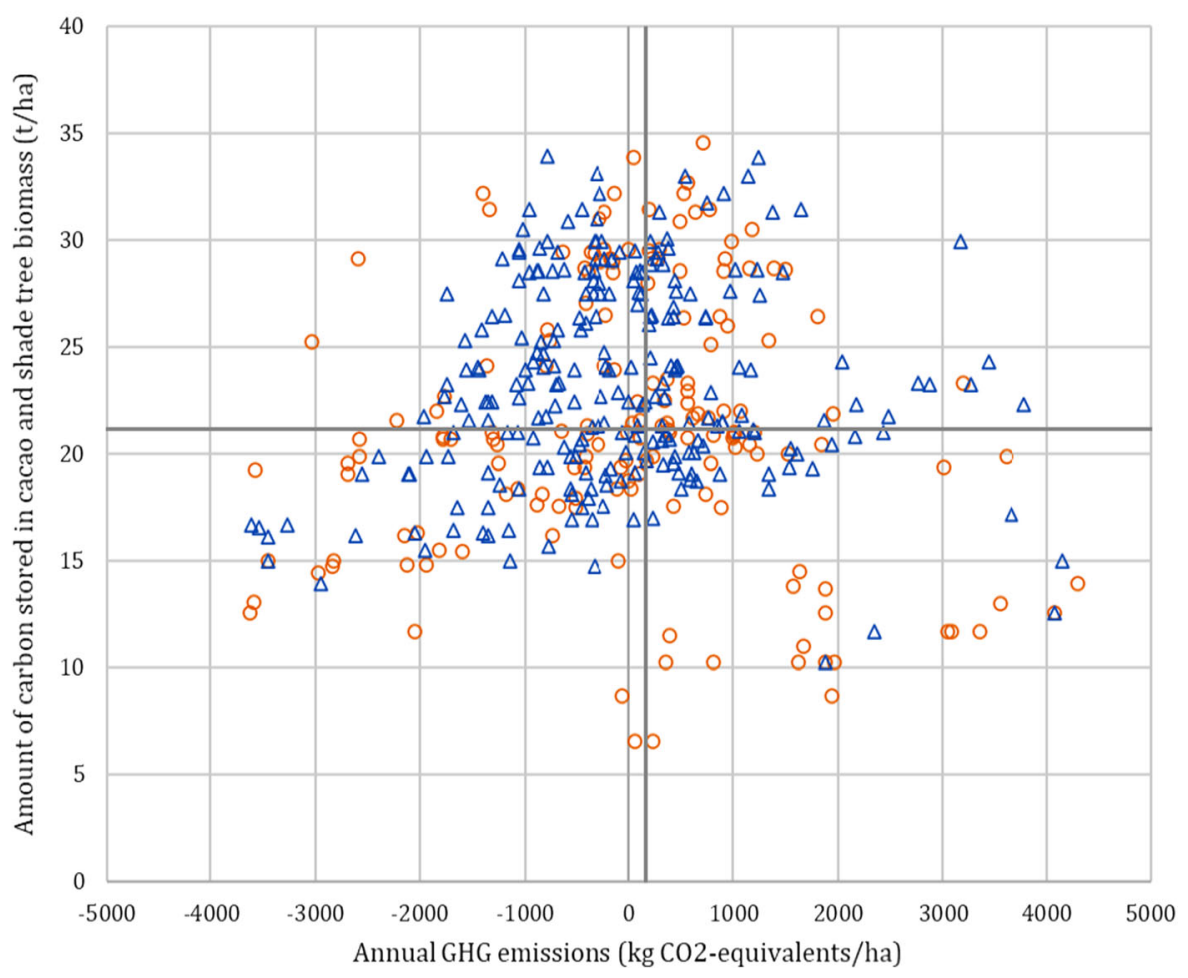

Fig. 4 Relation between annual GHG emissions (based on cacao and shade tree biomass, application of fertiliser and burning, composting and leaving on the ground biomass residues), carbon storage and plot yield. The solid grey line on the $X$-axis represents median annual GHG emissions per hectare

pesticides), more shade trees (especially in the first three years) and higher yields compared to the current agricultural practice. As a result, GAP are associated with a higher accumulation of carbon in shade tree biomass per hectare. This accumulation is less than expected, because although many shade trees are planted in year 0 to protect the cacao seedlings, most of these trees are removed in the years after. Furthermore, the GAP prescribes plantation renewal after 30 years, whereas the current plantations are cultivated much longer. This results in a limited total carbon accumulation in GAP for shade trees of 0.17 tonne $\mathrm{C}$ tree ${ }^{-1}$ compared to 0.24 tonne $\mathrm{C}$ tree ${ }^{-1}$ under the current practice and for cacao trees of 17 tonne $\mathrm{C}$ $\mathrm{ha}^{-1}$ compared to 19 tonne $\mathrm{C}$ ha $^{-1}$ under current practice. In contrast to the $\mathrm{C}$-stock, a shorter life span is beneficial for the annual $\mathrm{C}$ accumulation, which is relatively high in the first few years. Therefore, the annual $\mathrm{C}$ accumulation for GAP is higher, which and the solid grey line on the $Y$-axis represents median carbon storage per hectare. Plots indicated by a blue triangle in quadrant A are considered as climate-friendly, as those store above median carbon, emit below median GHGs and have above median yields. (Color figure online)

translates into lower GHG emissions, than under current practice. In GAP, deforestation is not allowed; hence, it is not responsible for GHG emissions. The contribution of inputs to the GHG emissions under GAP is relatively high with $3.4 \mathrm{~kg} \mathrm{CO}_{2} \mathrm{e}$ compared to $0,001 \mathrm{~kg} \mathrm{CO} 2 \mathrm{e}$ per kg cacao under current practice. The larger contribution of residue management to GHG emissions using GAP is a result of burning infected fruits and composting cacao husks, while the current practice is to leave the infected fruits and husks on the soil (associated with negative emissions). In total, the GHG emissions per hectare associated with cacao produced following GAP are higher than cacao produced under the current practice. The increase in cacao yield under GAP does not outweigh the increased GHG emissions, and hence, cacao produced following GAP is associated with $2.29 \mathrm{~kg} \mathrm{CO}_{2}$ e per $\mathrm{kg}$ cacao (see Table 2), compared to $1.47 \mathrm{~kg} \mathrm{CO}_{2}$ e per $\mathrm{kg}$ cacao resulting from the current practice (see Table 1). 
Table 2 The advised number of shade trees, use of inputs, its associated plot yields, and its modelled carbon stocks and the GHG emissions following GAP, as described by Ahoutou et al. (2015)

\begin{tabular}{ll}
\hline & Expressed in \\
\hline $\begin{array}{l}\text { Farm characteristics } \\
\text { Yield }\end{array}$ & In kg per hectare \\
Shade trees & Number per hectare \\
Carbon stock & \\
Cacao trees & Tonne C stored in above- and belowground biomass per hectare \\
Shade trees & Tonne C stored in above- and belowground biomass per hectare \\
GHG emissions & \\
Cacao biomass & $\mathrm{Kg} \mathrm{CO}_{2} \mathrm{e}$ accumulated yearly per kg yield \\
Shade tree biomass & $\mathrm{Kg} \mathrm{CO}_{2} \mathrm{e}$ accumulated yearly per kg yield \\
Residue management & $\mathrm{Kg} \mathrm{CO}_{2} \mathrm{e}$ per kg yield \\
Deforestation & $\mathrm{Kg} \mathrm{CO}_{2} \mathrm{e}$ per kg yield \\
Inputs & $\mathrm{Kg} \mathrm{CO}_{2} \mathrm{e}$ per kg yield \\
Background & $\mathrm{Kg} \mathrm{CO}_{2} \mathrm{e}$ per kg yield \\
Total GHG emissions & $\mathrm{Kg} \mathrm{CO}_{2} \mathrm{e}$ per kg yield \\
\hline
\end{tabular}

*1333, 667, 303 and 30 shade trees ha ${ }^{-1}$ in, respectively, in year 1, 2, 3, 4-30

\section{Discussion}

Carbon stored in the cacao system

An estimated 19 tonnes of $\mathrm{C}$ are stored in cacao biomass per hectare (see Table 1), and 23 tonnes when including the carbon stored in shade trees. These amounts fall within the wide range found in literature, from 11 tonnes of $\mathrm{C}$ per hectare stored in cacao tree biomass in a monoculture in Indonesia (Abou Rajab et al. 2016) to 231 tonnes of $\mathrm{C}$ per hectare in cacao and shade tree biomass in an agroforestry system in Cameroon (Norgrove and Hauser 2013). Keeping the average cacao tree density $\left(1111\right.$ trees ha $\left.^{-1}\right)$ and shade tree density ( 13 trees $\mathrm{ha}^{-1}$ ) in mind, the results of our study show that relatively large amounts of $\mathrm{C}$ are stored in the few shade trees (4-5 tonne $\mathrm{C} \mathrm{ha}^{-1}$ ) compared to carbon stored in the much higher number of cacao trees. Hence, the carbon stock expressed per tree is higher for shade trees than for cacao trees $(0.24$ and $0.02 \mathrm{t} \mathrm{C}$ tree ${ }^{-1}$, respectively). Similar values for cacao carbon stock $\left(0.01-0.02\right.$ t C tree $\left.{ }^{-1}\right)$ were found by other authors (Ngala 2015; Somarriba et al. 2013; Norgrove and Hauser 2013: Abou Rajab et al. 2016). For shade trees data in literature differed much more between 0.08-0.31 (Somarriba et al. 2013), 1.05 (Norgrove and Hauser 2013), 0.28-0.83 (Dawoe et al. 2016) and $0.13 \mathrm{t} \mathrm{C}$ tree $^{-1}$ (Abou Rajab et al. 2016). The relatively high carbon stock of shade trees in our study can be explained by the age of the shade trees who freely accumulated carbon over time, whereas the cacao trees have plateaued their above ground biomass due to regular pruning. Yet in our study the contribution of cacao trees to total $\mathrm{C}$ stock $(83 \%)$ is very high compared to other studies which is related to the high proportion of the trees in our fields being cacao trees. In contrast, in plots with even slightly higher cacao tree densities (1362 cacao trees $\mathrm{ha}^{-1}$ ), Norgrove and Hauser (2013) reported that the cacao trees contributed only $10 \%$ to the carbon stock in plots in Cameroon. In their study, the density of shade trees was 115 trees ha ${ }^{-1}$ and their $\mathrm{C}$ stock was very large with $1,05 \mathrm{tC}$ tree $^{-1}$, together accounting for the relatively large contribution of shade trees to the total $\mathrm{C}$ stock per plot. Their data also indicate that some trees may be remnant trees from the forest that was replaced by cacao and that these trees accumulated carbon even before cacao was planted. Sommariba et al. (2013) found in Central America that cacao biomass contributed $18 \%$ to the total carbon storage, which in this case is due to the relatively low cacao tree density ( 548 trees ha ${ }^{-1}$ ) and high shade tree density (321 trees $\mathrm{ha}^{-1}$ ). The absolute and relative contribution of cacao trees to the total carbon stock, 
found in our study, is in line with such contributions as found in literature, based on the number and age of shade trees compared to number and age of cacao trees in the same plots.

\section{GHG emissions related to cacao production}

The value of $1.47 \mathrm{CO}_{2} \mathrm{e}$ emitted per kilogram cacao beans found in our study in Cote d'Ivoire falls in the range reported by literature and is valid for the development and production phase for the average cacao yields of $430-440 \mathrm{~kg} \mathrm{ha}^{-1}$. The emissions calculated for GAP of $2.29 \mathrm{~kg} \mathrm{CO}_{2} \mathrm{e}$ per $\mathrm{kg}$ beans cacao for a yield of $1184 \mathrm{~kg} \mathrm{ha}^{-1}$ also fall within the range. Available studies report a net emission of GHGs per kilogram of cacao beans produced between 0.32 and $42 \mathrm{~kg} \mathrm{CO}_{2} \mathrm{e}$ per kilogram of cacao (Recanti et al. 2018; Ntiamoah and Afrane 2008; OrtizRodriguez et al. 2016; Harris et al. 2015; Konstantas et al. 2018; Defra 2009; Schroth et al. 2016) but they rarely relate these emissions explicitly to the level of cacao beans produced. Looking closer to the studies we will try to explain the differences. Ortiz-Rodriguez et al. (2016) assessed the carbon footprint of Colombian cacao systems using a Life Cycle Assessment (LCA) approach. For a fair comparison with our study, we considered only their data for the development and production phase, for which they found values of 7.84 and $9.22 \mathrm{~kg} \mathrm{CO} \mathrm{CO}_{2} \mathrm{e}$ per $\mathrm{kg}$ cacao. One of the main sources of the emissions is the application of lime. Additionally, leaving cacao husks on the soil is another main contributor to the GHG emissions (mainly as $\mathrm{CH}_{4}$ ), as they assume anaerobic conditions will occur. The application of lime is not included in our study and we associated leaving residues on the soil with negative emissions, which factors both contribute to the differences between our outcomes. Defra (2009) used the same LCA approach and included land-use change and export in the assessment and found a value of $42 \mathrm{CO}_{2} \mathrm{e} \mathrm{kg}^{-1}$ cacao. Land-use change was found to contribute $98 \%$ of the emissions during the whole process $\left(41.16 \mathrm{~kg} \mathrm{CO}_{2} \mathrm{e}\right.$ per $\mathrm{kg}$ cacao). Land-use change was also included in our study but resulted in $4.82 \mathrm{~kg} \mathrm{CO}_{2} \mathrm{e}$ per $\mathrm{kg}$ cacao. The origin of the differences between Defra (2009) and our study is difficult to trace, because Defra (2009) did not specify how the emissions from land use change were calculated. Schroth et al. (2016) executed a study very similar to our study, but excluded the emissions of biomass residue management and background emissions from the soil. Schroth et al. (2016) found that for the lower range in yields $\left(<285 \mathrm{~kg} \mathrm{ha}^{-1}\right)$, yields were negatively correlated to carbon stocks, which was not the case for the results of our study. Furthermore, they found a positive correlation between yield and input related emissions, which has also not been confirmed by our results. Besides, they conclude that high cacao yields $\left(570 \mathrm{~kg} \mathrm{ha}^{-1}\right.$ ) are compatible with low inputrelated GHGe $\left(0.25 \mathrm{~kg} \mathrm{CO}_{2} \mathrm{e} \mathrm{kg}^{-1}\right)$ and high carbon stocks $\left(65 \mathrm{tha}^{-1}\right)$, which is in line with the results of our study. Ntiomoah and Afrane (2008) assessed the global warming potential (GWP) associated with cacao production and processing in Ghana as well as transportation by following a LCA approach, including pesticides and chemical fertilisers, but whether components such as tree biomass, soil emissions, landuse-change and deforestation are included is not mentioned. The production phase only contributed about $18 \%$ to GWP. Reductions of $50 \%$ in use of inorganic fertiliser did hardly affect GWP; hence, the contribution of fertilisers to the GHG emissions was very low in Ghana which is in line with our study for Côte d'Ivoire. Overall, we need to conclude that results of different studies are difficult to compare, because a mixture of different system boundaries, components and calculation approaches were used, and transparency in the emissions associated with each component is often missing. We advocate for standardisation including all the main processes, to be able to benchmark various production systems.

\section{Cacao growth curve function}

Calvo Romero (2018) assessed the biomass growth of cacao trees of one cultivation type at different ages by destructive measurements. He concluded that the biomass growth of cacao trees levels off at an age of five years, as a result of pruning. Although the regression line explains only $21 \%$ of the variation in total weight by plant age, the data points collected by Zuidema et al. (2003) also indicate that cacao tree biomass levels off at an age between 5 and 10 years. The perennial GHG model fits a biomass growth curve in the form of a power function which is not able to reach a plateau, even when the data points give rise to such a function (see Appendix 3). The perennial GHG model therefore assumes cacao trees to grow endlessly in time, possibly overestimating cacao biomass in 
above five year old cacao plantations. However, the accessory uncertainty is expected to be neglectable, since it is very common to prune cacao trees, and therefore the actual biomass growth is restricted by pruning. In our model calculations, we include this pruning effect.

Are farmers interested in climate friendly cacao?

Planting trees on farms can be considered strategic management as it has long term effects and changes a farm's characteristic from full sun to agroforestry. Both Dumont et al (2014) and Atangana et al (2021) found a rich diversity of trees in cacao fields in Côte d'Ivoire. Amongst most cited advantages were the protection of cacao trees from heat stress, especially in the dry season, and soil fertility improvement. The most frequently planted species were exotic fruit trees used for nutrition and income, while timber tree species were mostly spared when clearing land for cacao production. The number of tree species per farm increased with expected benefits and experience in tree planting (Atangana et al. 2021). As much as $95 \%$ of the farmers wanted even more trees and/or more tree species (Dumont et al. 2014). However, Dawoe et al (2016) found that cacao farmers in Ghana removed trees because they contributed to pests and diseases and competed for resources leading to lower cacao yields. Clearly there must be an optimum and Blaser et al (2018) found that cacao yield would not be compromised at a $30 \%$ shade cover.

In the future, additional incentives may be reaped from payment for carbon sequestration. Dawoe et al (2016) suggested that cacao monoculture and cacao agroforestry could both be eligible for such payments but only when they would comply to the Ghanaian definition of forest such as plots being a minimum of 1 ha, having at least $15 \%$ canopy cover and containing trees that are $5 \mathrm{~m}$ tall. Five $\mathrm{m}$ would be too high for cacao trees but the shade trees in the cacao system could constitute a forest by complying to the requirements. Our study showed that net carbon sequestration will be difficult in situations with high background emissions, not just for cacao, but for any agricultural activity. And accounting for deforestation in the establishment phase leads to high carbon debts that need to be compensated for. Yet, perennial crops such as cacao have the possibility to sequester carbon in tree biomass which might be rewarded. A study by
Seeberg-Elverfeldt et al (2008) in cacao systems in Indonesia showed that for differentiated carbon prices up to $€ 32$ per $\mathrm{t} \mathrm{CO}_{2}$ e the majority of the households had an incentive to adopt the more sustainable shade intensive agroforestry system. Against current, much lower, carbon prices they were not interested because the amount of carbon stored is not so high and the contribution to household income would be very low. A study by Kenfack et al. (2020) in Cameroon shows that that farmers' interest to actually plant trees is much less in cacao systems that still contain remnant trees from the forest. These agroforestry systems may however already be climate friendly and qualify for payment for ecosystem services in their current status.

Hence, planting trees or saving forest trees during establishment is not only good for climate change mitigation, it also fits to farmers wishes and offers opportunities to economic benefits now or in the future.

\section{Conclusion}

As there is a growing demand for environmentally friendly grown cacao while at the same time improving the livelihoods of smallholders in the Republic of Côte d'Ivoire, insights in the GHG emissions related to cacao yield are needed. In our study, we quantified the on field GHG emissions related to the cacao production by using and adjusting the perennial GHG model and the CFT which gave outputs that are within the ranges found in other studies. However, a fair comparison is difficult as studies used a mixture of different system boundaries, components and calculation approaches, and transparency in the emissions associated with each component is often missing. It would be a step forward when a standardised and fully transparent approach including all the main processes could be used for benchmarking different cacao production systems. Our approach based on CFT could be a candidate to be used as standard for field level emissions and carbon sequestration and as such also be used as basis to make LCA approaches more comparable.

On average, the production of $1 \mathrm{~kg}$ cacao is associated with an emission of $1.47 \mathrm{~kg} \mathrm{CO}_{2} \mathrm{e}$, which is equal to an emission of $652 \mathrm{~kg} \mathrm{CO}_{2} \mathrm{e} \mathrm{ha}^{-1}$. The results revealed that producing high yields while at the same time storing a high amount of carbon and causing 
low GHG emissions is feasible mainly in old fields with high numbers of shade trees and proper residue management. Deforestation at establishment was a large contributor to GHG emissions. Cacao produced under the current GAP as described by Ahoutou et al. (2015) led to higher emissions of $2.29 \mathrm{~kg} \mathrm{CO}_{2} \mathrm{e}$ per $\mathrm{kg}$ of beans, despite assumed zero deforestation. The GHG emissions resulting from the use of inputs and residue management guided by needs for pest and disease control, outweigh the increase in cacao yield. Yet these emissions can be reduced by adapted residue management, different nutrient applications, and by leaving shade trees in the field at replanting. GAP recommendations aiming at high cacao yields may need to be revisited to incorporate climate mitigations objectives.

Finally, farmers are the managers of their cacao fields. Saving forest trees and planting trees in current cacao fields has their interest, not so much for climate mitigation, but for climate adaptation and for economic benefits such as fruits and potential future benefits in terms of carbon credits. They will need to balance the proportion of cacao trees and shade trees in a plot in relation to cacao yields and shade tree economic benefits, while aiming to be climate friendly.

Acknowledgements The authors are grateful for the support of the following organisations. The research was conducted within the Dutch Science Foundation (NWO-WOTRO) funded project W08.250.305 Cacao Crop Improvements, Farms And Markets: A science based approach to sustainably improve farmers food security in Ghana and Ivory Coast (CoCIFAM). Data on cacao pods and cacao allometry were collected at Divo, the research station of Centre National de Recherche Agricole
(CNRA) in Côte d'Ivoire. Farm survey data were provided by UTZ.

Open Access This article is licensed under a Creative Commons Attribution 4.0 International License, which permits use, sharing, adaptation, distribution and reproduction in any medium or format, as long as you give appropriate credit to the original author(s) and the source, provide a link to the Creative Commons licence, and indicate if changes were made. The images or other third party material in this article are included in the article's Creative Commons licence, unless indicated otherwise in a credit line to the material. If material is not included in the article's Creative Commons licence and your intended use is not permitted by statutory regulation or exceeds the permitted use, you will need to obtain permission directly from the copyright holder. To view a copy of this licence, visit http://creativecommons.org/licenses/by/4.0/.

Funding Field work was conducted within the Dutch Science Foundation (NWO-WOTRO) funded project W08.250.305 Cacao Crop Improvements, Farms And Markets: A science based approach to sustainably improve farmers food security in Ghana and Ivory Coast (CoCIFAM). The funding agency had no interference with data analysis, interpretation or publication. The authors have no relevant financial or non-financial interests to disclose. Survey data were provided by UTZ for the particular use for this publication only and not publicly available. Field data regarding the cacao pod study and model code are available with corresponding author on reasonable request.

\section{Appendix}

Appendix 1: Cacao tree biomass information

See Table 3. 
Table 3 Cacao tree biomass parameters for different plant parts required for the calibration of the perennial GHG model, sourced from literature

\begin{tabular}{|c|c|c|c|}
\hline & Expressed in & Mean & Source \\
\hline \multicolumn{4}{|l|}{ Cacao tree biomass } \\
\hline Woody biomass & Kilogram per tree & 16.06 & $1,2,3,4,5,6,7,8$ \\
\hline Leaf biomass & Kilogram per tree & 2.18 & $1,2,4,5,6,9,10,11,12,13$ \\
\hline Belowground biomass & Kilogram per tree & 5.47 & $2,4,5,6,7,8,9,10,11,12,13,14,15,16$ \\
\hline Dry matter wood & Percentage dry material & 41.33 & 4 \\
\hline Dry matter leaf & Percentage dry material & & 4 \\
\hline Dry matter fruit & Percentage dry material & 20 & Fieldwork \\
\hline Dry matter beans & Percentage dry material & 33 & Fieldwork \\
\hline Dry matter husk & Percentage dry material & 15 & Fieldwork \\
\hline Carbon wood & Carbon fraction & 48.32 & $4,16,17,18,19$ \\
\hline Nitrogen wood & Nitrogen fraction & 1.17 & $1,4,10,13,20,21,22$ \\
\hline Carbon leaf & Carbon fraction & 45.86 & $4,17,19$ \\
\hline Nitrogen leaf & Nitrogen fraction & 1.81 & $1,4,13,20,21,22,23,24,25,26,27$ \\
\hline Carbon roots & Carbon fraction & 47.06 & 4,19 \\
\hline Nitrogen roots & Nitrogen fraction & 0.63 & 4 \\
\hline Carbon fruit & Carbon fraction & 49.92 & $4,17,28$ \\
\hline Nitrogen fruit & Nitrogen fraction & 2.01 & $3,4,21,27,28,29,30,31,32,33,34,35$ \\
\hline Percentage husk & Percentage husk of fruit in dry matter & 61 & Fieldwork \\
\hline Percentage beans & Percentage beans of fruit in dry matter & 39 & Fieldwork \\
\hline Unsuitable fruits & Percentage unsuitable/infected fruits & 30.00 & $36,37,38$ \\
\hline Decomposition wood & Decomposition parameter $k$ & 1.27 & 39 \\
\hline Decomposition litter & Decomposition parameter $k$ & 0.63 & 39 \\
\hline Decomposition root & Decomposition parameter $k$ & 1.00 & 34,40 \\
\hline Decomposition fruit & Decomposition parameter $k$ & 1.64 & 39 \\
\hline Decomposition husk & Decomposition parameter $k$ & 1.64 & 39 \\
\hline Cacao trees that die & Number of cacao trees per hectare that die annually & $0 *$ & 38 \\
\hline
\end{tabular}

1: Alpízar et al. (1986). 2: Beer et al. (1990). 3: Boyer (1973). 4: Calvo Romero (2018). 5: Fisher (2018). 6: Moser et al. (2010). 7: Abou Rajab et al. (2016). 8: Subler (1994). 9: Alves dos Santos et al. (2018). 10: Baligar and Fageria (2017). 11: Da Silva Branco et al. (2017). 12: Isaac et al. (2011). 13: Isaac et al. (2007b). 14: Borden et al. (2017). 15: Oladele (2015). 16: Smiley and Kroschel (2008). 17: Silatsa et al. (2017). 18: N'Guessa N'Gbala et al. (2017). 19: Mohammed et al. (2016). 20: Isaac et al. (2007a). 21: Fassbender et al. (1988). 22: Heuveldop et al. (1988). 23: Shamshuddin et al. (2011). 24: International Organization for Standardization (1997). 25: Wessel (1971). 26: Pérez-Flores et al. (2018). 27: Afrifa et al. (n.d.). 28: Craven et al. (2007). 29: Aranguren et al. (1982). 30: De Oliveira Leite and Valle (1990). 31: Thong and Ng (1978). 32: Hartemink (2005). 33: Zuidema et al. (2005). 34: Van Vliet and Giller (2017). 35: Santana and Cabala-Rosand (1982). 36: Vanhove et al. (2015). 37: Ten Hoopen et al. (2012). 38: Wessel and Quist-Wessel (2015). 39: Materechera (2010). 40: Muñoz and Beer (2001)

*Due to replanting

Appendix 2: Sensitivity analysis

Identifying sensitive parameters provides an useful indication to see which parameters require further research. The sensitivity was analysed by the absolute effect on manipulating the parameters of cacao biomass on the modelled GHG emissions and the elasticity. Elasticities are calculated as following: elasticity $=\frac{\% \Delta Y}{\% \Delta X} \quad($ Pannell 1997). The elasticities provide an indication of the parameters to which the GHG-emission is most sensitive (Pannell 1997).

A simple sensitivity analysis regarding biomass is conducted with biomass data obtained from Supplementary information S2, provided by Ledo et al. 
Table 4 Changes in GHG emissions for alterations in multiple parameters biomass

\begin{tabular}{lccc}
\hline Biomass & GHG emissions in tonne per hectare & & Elasticity \\
\hline Standard & 647,321 & $-10 \%$ & - \\
Biomass part & $+10 \%$ & 582,592 & -0.9999521 \\
Fruit & 712,050 & 647,321 & 0.0000000 \\
Wood & 647,321 & 647,320 & -0.0000154 \\
Leaf & 647,322 & 647,323 & 0.0000309 \\
Root & 647,319 & & \\
\hline
\end{tabular}

(2018). The values of the fruit, wood, leaf and fruit biomass are multiplied with 1.1 and 0.9 to assess their sensitivity. All MPs are assumed to be applied in the modelled GHG emissions, to get a representative effect for all the biomass parts.

The outcomes of the sensitivity analysis are shown in Table 4. The outcomes show that changes in the wood, leaf and root biomass weight only have a limited effect on the GHG emissions in tonne per hectare. Albeit only a small effect, the fruit-parameter has the strongest effect on the GHG emissions. Nonetheless, a $10 \%$ change in plant part parameters does not affect the coefficients extremely.

Appendix 3: Cacao tree biomass modelled by the perennial GHG model

See Fig. 5.

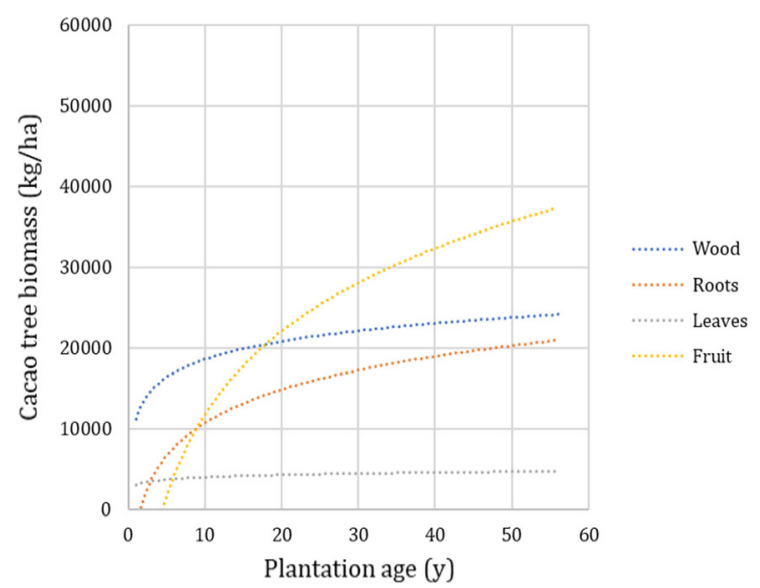

Fig. 5 Simulated cacao tree biomass as output of the perennial GHG model

\section{References}

Abenyega O, Gockowski J (2003) Labor practices in the cocoa sector of Ghana with a special focus on the role of children. International Institute of Tropical Agriculture, Ibadan

Abou Rajab Y, Leuschner C, Barus H, Tjoa A, Hertel D (2016) Cacao cultivation under diverse shade tree cover allows high carbon storage and sequestration without yield losses. PLoS ONE 11:1-22. https://doi.org/10.1371/journal.pone. 0149949

Afrifa AA, Dogbatse JA, Arthur A (n.d.) Using integrated plant nutrient management strategy for sustainable and competitive cocoa production in Ghana. Cocoa Research Institute of Ghana

Ahoutou K, Yaméogo I, Assiri A, Ehougban V (2015) Manuel Technique de Cacaoculture durable - A l'Attention du Technicien. Abidjan, Côte d'Ivoire: Le Conseil du CaféCacao

Alpízar L, Fassbender HW, Heuveldop J, Fölster H, Enríquez G (1986) Modelling agroforestry systems of cacao (Theobroma cacao) with laurel (Cordia alliodora) or poro (Erythrina poeppigiana) in Costa Rica. Agrofor Syst 4:175-189

Alves dos Santos E, Furtado de Almeida A, da Silva Branco MC, Conceicao dos Santos I, Ahner D, Baligar VC, Valle RR (2018) Path analysis of phenotypic traits in young cacao plants under drought conditions. https://doi.org/10.1371/ journal.pone.0191847

Apshara E (2017) Comparative study on clonal and seedling progenies of selected cocoa (Theobroma cacao L.) genotypes. Indian J Horticult 74:168-172. https://doi.org/10. 5958/0974-0112.2017.00037.8

Aranguren J, Escalante G, Herrera R (1982) Nitrogen cycle of tropical perennial crops under shade trees. Plant Soil 67:259-269

Atangana AR, Gnangoh JZ, Yao AK, Kouakou TD, MianNdriNda A, Kouamé C (2021) Rebuilding tree cover in deforested cocoa landscapes in Côte d'Ivoire: factors affecting the choice of species planted. Forests 12:1988. https://doi.org/10.3390/f12020198

Baligar VC, Fageria NK (2017) Influence of nitrogen forms and levels on the growth and nutrition of cacao. J Plant Nutr 40:709-718. https://doi.org/10.1080/01904167.2016. 1262401 
Beer J, Bonnemann A, Chavez W, Fassbender HW, Imbach AC, Martel I (1990) Modelling agroforestry systems of cacao (Theobroma cacao) with laurel (Cordia alliodora) or poro (Erythrina poeppigiana) in Costa Rica. Agrofor Syst 12:229-249

Blaser WJ, Oppong J, Hart SP, Landolt J, Yeboah E, Six J (2018) Climate-smart sustainable agriculture in low-to-intermediate shade agroforests. Nat Sustain 1:234-239. https://doi. org/10.1038/s41893-018-0062-8

Borden KA, Anglaaere LCN, Adu-Bredu S, Isaac ME (2017) Root biomass variation of cocoa and implications for carbon stocks in agroforestry systems. Agrofor Syst. https:// doi.org/10.1007/s10457-017-0122-5

Boyer J (1973) Cycles de la matière organique des éléments minéraux dans une cacaoyére camerounaise. Café Cacao Thé 18:3-30

Calvo Romero F (2018) Biomass and nutrient distribution in cacao trees (Theobroma cacao): a case study in Côte d'Ivoire. M.Sc. thesis, Plant Production Systems Group. Wageningen University and Research Institute

Clavreul J, Btunar I, Rubio V, King H (2017) Intra- and interyear variability of agricultural carbon footprints: a case study on field-grown tomatoes. J Clean Prod 158:156-164. https://doi.org/10.1016/j.jclepro.2017.05.004

Craven D, Braden D, Ashton MS, Berlyn GP, Wishnie M, Dent D (2007) Between and within-site comparisons of structural and physiological characteristics and foliar nutrient content of 14 tree species at a wet, fertile site and a dry, infertile site in Panama. For Ecol Manag 238:335-346

Da Silva Branco MC, Furtado de Almeida A, Dalmolin AC, Ahnert D, Baligar VC (2017) Influence of low light intensity and soil flooding on cacao physiology. Sci Hortic 217:243-257

Dawoe E, Asante W, Acheampong E, Bosu P (2016) Shade tree diversity and aboveground carbon stocks in Theobroma cacao agroforestry systems: implications for REDD+ implementation in a West African cacao landscape. Carbon Balance Manag 1:1-13. https://doi.org/10.1186/s13021016-0061-X

Daymond AJ, Hadley, (2008) Differential effects of temperature on fruit development and bean quality of contrasting genotypes of cacao (Theobroma cacao). Ann Appl Biol 153:175-185. https://doi.org/10.1111/j.1744-7348.2008. 00246

De Oliveira LJ, Valle RR (1990) Nutrient cycling in the cacao ecosystem: rain and throughfall as nutrient sources for the soil and the cacao tree. Agricult Ecosyst Environ $32: 143-154$

Defra (2009) Scenario building to test and inform the development of a BSI method for assessing GHG emissions from food. Cranfield University, Bedford

Dumont ES, Gnahoua GM, Ohouo L, Sinclair L, Vaast P (2014) Farmers in Côte d'Ivoire value integrating tree diversity in cocoa for the provision of ecosystem services. Agrofor Syst 88:1047-1066. https://doi.org/10.1007/s10457-014-96794

Fassbender HW, Alpízar L, Heuveldop J, Fölster H, Enríquez G (1988) Modelling agroforestry systems of cacao (Theobroma cacao) with laurel (Cordia alliodora) and poro (Erythrina poeppigiana) in Costa Rica. Agrofor Syst 6:49-1988
Fisher D (2018) Biomass, nutrient content and allometric relations of 1, 6 and 11-year-old, intensively grown Cocoa (Theobroma cacao) trees. M.Sc. thesis, Plant Production Systems group. Wageningen University Research Institute

Gama-Rodrigues EF, Gama-Rodrigues AC, Nair RPK (2011) Soil carbon sequestration in cacao agroforestry systems: a case study from Bahia, Brazil. In: Kumar BM, Nair PKR (eds) Carbon Sequestration potential of agroforestry systems: opportunities and challenges, vol 8. Advances in Agroforestry. pp 85-99. https://doi.org/10.1007/978-94007-1630-8_5

Gockowski J, Sonwa D (2011) Cocoa intensification scenarios and their predicted impact on $\mathrm{CO}_{2}$ emissions, biodiversity conservation, and rural livelihoods in the Guinea rain forest of West Africa. Environ Manag 48:307-321. https://doi. org/10.1007/s00267-010-9602-3

Harris N, Payne O, Mann SA (2015) How much rainforest is in that chocolate bar. World resources institute, Washington DC, United States. Available at: https://www.wri.org/ insights/how-much-rainforest-chocolate-bar

Hartemink AE (2005) Nutrient stocks, nutrient cycling and soil changes in cocoa ecosystems-a review. Adv Agron 86:227-253. https://doi.org/10.1016/S00652113(05)86005-5

Henry M, Picard N, Trotta C, Manlay RJ, Valentini R, Bernoux M, Saint-André L (2011) Estimating tree biomass of subSaharan African forests: a review of available allometric equations. Silva Fennica 45:477-569

Heuveldop J, Fassbender HW, Alpizar L, Enriquez G, Folster H (1988) Modelling agroforestry systems of cacao (Theobroma cacao) with laurel (Cordia alliodora) and poro (Erythrina poeppigiana) in Costa Rica. II. Cacao and wood production, litter production and decomposition. Agrofor Syst 6:37-48

Hillier J, Walter C, Malin D, Garcia-Suarez T, Mila-i-Canals L, Smith P (2011) A farm-focused calculator for emissions from crop and livestock production. Environ Model Softw 26:1070-1078. https://doi.org/10.1016/j.envsoft.2011.03. 014

Ingram V, Waarts Y, Ge, L, van Vugt S, Wegner L, PuisterJansen L, Ruf F, Tanoh R (2013) The IDH Cocoa Productivity and Quality Programme (CPQP) in Côte d'Ivoire. Impact assessment framework and baseline. LEI Wageningen UR. Den Haag, the Netherlands

Ingram V, Waarts Y, Ge L, van Vught S, Wegner L, PuisterJansen L, Ruf F, Tanoh R (2017) UTZ Data Endline Report Cocoa CDI

International Organization for Standardization (1997) Environmental management-life cycle assessment-principles and framework 14040. ISO, Geneva, Switzerland

Isaac ME, Timmer VR, Quashie-Sam SJ (2007) Shade tree effects in an 8-year-old cocoa agroforestry system: biomass and nutrient diagnosis of Theobroma cacao by vector analysis. Nutr Cycl Agroecosyst 78:155-165

Isaac ME, Ulzen-Appiah F, Timmer VR, Quashie-Sam SJ (2007) Early growth and nutritional response to resource competition in cocoa-shade intercropped systems. Plant Soil 298:243-254. https://doi.org/10.1007/s11104-0079362-x

Isaac ME, Adjei O, Issaka RN, Timmer VR (2011) A strategy for tree-perennial crop productivity: nursery phase nutrient 
additions in cocoa-shade agroforestry systems. Agrofor Syst 81:147-155

ISRIC (2019) Soil Data Hub. Retrieved from ISRIC website

Kenfack Essougong UP, Slingerland M, Mathe S, Vanhove W, Ijang Tata Ngome P, Giller KE, Boudes P, Woitties LS, Leeuwis C (2020) Understanding soil fertility management practices of cocoa farmers in the humid forest and forestsavannah transition zone of Cameroon. Hum Ecol 48:709-720

Konstantas A, Jeswani HK, Stamford L, Azapagic A (2018) Environmental impacts of chocolate production and consumption in the UK. Food Res Int 106:1012-1025. https:// doi.org/10.1016/j.foodres.2018.02.042

Ledo A, Heathcote R, Hastings A, Smith P, Hiller J (2018) Perennial-GHG: a new allometric model to estimate biomass accumulation and greenhouse gas emissions in perennial food and bioenergy crops. Environ Model Softw 102:292-305. https://doi.org/10.1016/j.envsoft.2017.12. 005

Lockwood G, Pang Thau Yin J (1996) Yields of cocoa clones in response to planting density in Malaysia. Explor Agric 32:41-47. https://doi.org/10.1017/S0014479700025837

Materechera SA (2010) Utilisation and management practices of animal manure for replenishing soil fertility among smallscale crop farmers in semi-arid farming districts of the North West Province, South Africa. Nutr Cycl Agroecosyst 87:415-428. https://doi.org/10.1007/s10705-0109347-7

Mohammed AM, Robinson JS, Midmore D, Verhoef A (2016) Carbon storage in Ghanaian cocoa ecosystems. Carbon Balance Manag. https://doi.org/10.1186/s13021-0160045-x

Montagnini F, Nair PKR (2004) Carbon sequestration: an underexploited environmental benefit of agroforestry systems. New Vistas n Agrofor 1:281-295. https://doi.org/10. 1007/978-94-017-2424-1_20

Moser G, Leuschner C, Hertel D, Hölscher D, Köhler M, Leitner D, Michalzik B, Prihastanti E, Tjitrosemito S, Schwendenmann L (2010) Response of cocoa trees (Theobroma cacao) to a 13-month desiccation period in Sulawesi, Indonesia. Agrofor Syst 79:171-187

Muñoz F, Beer J (2001) Fine root dynamics of shaded cacao plantations in Costa Rica. Agrofor Syst 51:119-130. https://doi.org/10.1023/A:1010651203815

Myhre G, Shindell D, Bréon FM, Collins W, Fuglestvedt J, Huang J et al (2013) Anthropogenic and natural radiative forcing. In: Stocker TF, Qin D, Plattner GK, Tignor M, Allen SK, Doschung J et al (eds) Climate change 2013: the physical science basis. Contribution of working group I to the fifth assessment report of the intergovernmental panel on climate change. Cambridge University Press, Cambridge, pp 659-740. https://doi.org/10.1017/ CBO9781107415324.018

N'Guessa N'Gbala F, Martinez Guéi A, Ebagnerin Tondoh J (2017) Carbon stocks in selected tree plantations, as compared with semi-deciduous forests in centre-west Côte d'Ivoire. Agr Ecosyst Environ 239:30-37

Nelson V, Phillips D (2018) Sector, landscape or rural transformations? Exploring the limits and potential of agricultural sustainability initiatives through a cocoa case study.
Business strategy and the environment. https://doi.org/10. 1002/bse. 2014

Ngala TJ (2015) Effect of shade trees on cocoa yield in smallholder cocoa (Theobroma cacao) agroforests in Tabla, Centre Cameroon. Thesis, crop sciences. University of Dschang, Cameroon

Norgrove L, Hauser S (2013) Carbon stocks in shaded Theobroma cacao farms and adjacent secondary forests of similar age in Cameroon. Tropic Ecol 54(1):15-22

Ntiamoah A, Afrane G (2008) Environmental impacts of cocoa production and processing in Ghana: life cycle assessment approach. J Clean Prod 16:1735-1740. https://doi.org/10. 1016/j.jclepro.2007.11.004

Oladele SO (2015) Mycorrhizal fungus (glous Mossae) inoculation effects on performance and root biomass development of cacao seedling in the nursery. Agric for 61:69-76. https://doi.org/10.17707/AgricultForest.61.3.07

Onyekwelu JC (2007) Growth, biomass yield and biomass functions for plantation-grown Nauclea diderrichii (de wild) in the humid tropical rainforest zone of south-western Nigeria. Biores Technol 98:2679-2687. https://doi.org/10. 1016/j.biortech.2006.09.023

Ortiz-Rodriguez OO, Villamizar R, Naranjo C, Carcia-Caceres RG (2016) Carbon footprint of the Colombian cocoa production. Eng Agric 36:260-270. https://doi.org/10.1590/ 1809-4430-Eng.Agric.v36n2p260-270/2016

Pérez-Flores J, Pérez AJ, Suárez YP, Bolaina VC, Quiroga AL (2018) Leaf litter and its nutrient contribution in the cacao agroforestry system. Agrofor Syst 92:365-374

Recanati F, Marveggio D, Dotelli G (2018) From beans to bar: a life cycle assessment towards sustainable chocolate supply chain. Sci Total Environ 613-614:1013-1023. https://doi. org/10.1016/j.scitotenv.2017.09.187

Saj S, Jagoret P, Essola Etoa L, Eteckji Fonkeng E, Ngala Tarla J, Essobo Nieboukaho J, Mvondo Sakouma K (2017) Lessons learned from the long-term analysis of cacao yield and stand structure in central Cameroonian agroforestry systems. Agric Syst 156:95-104. https://doi.org/10.1016/j. agsy.2017.06.002

Santana MBM, Cabala-Rosand P (1982) Dynamics of nitrogen in a shaded cacao plantation. Plant Soil 67:271-281

Schneidewind U, Niether W, Armengot L, Schneider M, Sauer D, Heitkamp F, Gerold G (2018) Carbon stocks, litterfall and pruning residues in monoculture and agroforestry cacao production systems. Exp Agric. https://doi.org/10. 1017/S001447971800011X

Schroth G, Laderach P, Martinez-Valle AI, Bunn C, Jassogne L (2014) Vulnerability to climate change of cocoa in West Africa: patterns, opportunities and limits to adaptation. Sci Total Environ 556:231-241. https://doi.org/10.1016/j. scitotenv.2016.03.024

Schroth G, Jeusset A, da Silva GA, Florence CT, Coelho NAP, Faria D, Läderach P (2016) Climate friendliness of cocoa agroforests is compatible with productivity increase. Mitig Adapt Strategy Global Change 21:67-80. https://doi.org/ 10.1007/s11027-014-9570-7

Seeberg-Elverfeldt C, Schwarze S, Zeller M (2008) Payments for environmental services-incentives through carbon sequestration compensation for cocoa-based agroforestry systems in Central Sulawesi, Indonesia. Department of Agricultural Economics and Social Sciences in the Tropics 
and Subtropics (Ed.), Forschung zur Entwicklungsökonomie und -politik Research in Development Economics and Policy, Discussion Paper No. 02/2008. ISSN 1439-4952

Shamshuddin J, Anda M, Fauziah CI, Syed Omar SR (2011) Growth of cocoa planted on highly weathered soil as affected by application of basalt and/or compost. Commun Soil Sci Plant Anal 42:2751-2766. https://doi.org/10.1080/ 00103624.2011 .622822

Silatsa FBT, Yemefack M, Ewane-Nonga N, Kemga A, Hanna R (2017) Modelling carbon stock dynamics under fallow and cocoa agroforest systems in the shifting agricultural landscape of Central Cameroon. Agrofor Syst 91:993-1006. https://doi.org/10.1007/s10457-016-9973-4

Somarriba E, Cerda R, Orozco L, Cifuentes M, Dávila C, Espin T, Mavisoy H, Avila G, Alvarado E, Poveda V, Astorga C, Say E, Deheuvels O (2013) Carbon stocks and cocoa yields in agroforestry systems of Central America. Agric Ecosyst Environ 173:56-57. https://doi.org/10.1016/j.agee.2013. 04.013

Smiley GL, Kroschel J (2008) Temporal change in carbon stocks of cocoa-gliricidia agroforests in Central Sulawesi, Indonesia. Agrofor Syst 73:219-231. https://doi.org/10. 1007/s10457-008-9144-3

Subler S (1994) Allometric relations for estimating the aboveground biomass of cacao stands in the Eastern Amazon basin. Agrotropica 6:65-72

Ten Hoopen GM, Deberdt P, Mbenoun M, Cilas C (2012) Modelling cacao pod growth: implications for disease control. Ann Appl Biol. https://doi.org/10.1111/j.17447348.2012.00539.x

Thong KC, Ng WL (1978) Growth and nutrient composition of monocrop cocoa plants on inland Malaysian soils. In: Proceedings of the international conference on cocoa and coconuts, Kuala Lumpur, Malaysia, pp 262-287
Van Rikxoort H, Schroth G, Läderach P, Rodríguez-Sánchez B (2014) Carbon footprints and carbon stocks reveal climatefriendly coffee production. Agron Sustain Dev 34:887-897. https://doi.org/10.1007/s13593-014-0223-8

Van Vliet J, Giller KE (2017) Mineral nutrition of cocoa: a review. Adv Agron 141:158-270

Vanhove W, Vanhoudt N, van Damme P (2015) Effect of shade tree planting and soil management on rehabilitation success of a 22-year-old degraded cocoa plantation. Agr Ecosyst Environ 219:14-25. https://doi.org/10.1016/j. agee.2015.12.005

Vriesmann LC, de Mello Castanho Amboni RD, de Oliveira Petkowicz CL (2011) Cacao pod husks (Theobroma cacao L.): Composition and hot-water-soluble pectins. Ind Crops Prod 34:1173-1181. https://doi.org/10.1016/j.indcrop. 2011.04.004

Wessel M, Quist-Wessel PMF (2015) Cocoa production in West Africa, a review and analysis of recent developments. Wageningen J Life Sci 74-75:1-7. https://doi.org/10.1016/ j.njas.2015.09.001

Wessel M (1971) Fertilizer requirements of cacao (Theobroma cacao L.) in south-western Nigeria (Doctoral dissertation). Koninklijk instituut voor de tropen, Amsterdam, the Netherlands

Zuidema PA, Leffelaar PA, Gerritsma W, Mommer L, Anten PR (2005) A physiological production model for cocoa (Theobroma cacao): model presentation, validation and application. Agric Syst 84:195-225. https://doi.org/10. 1016/j.agsy.2004.06.015

Publisher's Note Springer Nature remains neutral with regard to jurisdictional claims in published maps and institutional affiliations. 